\title{
Disparity in soil bacterial community succession along a short time-scale deglaciation chronosequence on the Tibetan Plateau
}

\author{
Ajmal Khan ${ }^{1,2}$, Weidong Kong ${ }^{1,2,}{ }^{*}$, Mukan $\mathrm{Ji}^{1}$, Linyan Yue ${ }^{1,2}$, Yue $\mathrm{Xie}^{3}$, Jinbo Liu ${ }^{1}$, Baiqing $\mathrm{Xu}^{3}$ \\ 1 Key Laboratory of Alpine Ecology and Biodiversity, Institute of Tibetan Plateau Research, Chinese Academy of Sciences, \\ Beijing 100101, China \\ 2 College of Resources and Environment, University of Chinese Academy of Sciences, Beijing 100039, China \\ 3 Key Laboratory of Tibetan Environmental Changes and Land Surface Processes, Institute of Tibetan Plateau Research, Chinese Academy of \\ Sciences, Beijing 100101, China
}

\section{ARTICLE INFO}

\section{Article history:}

Received October 19, 2019

Revised January 8, 2020

Accepted February 17, 2020

Keywords:

Deglaciated soils

Bacterial community

Bacterial succession

Tibetan Plateau

Deglaciation chronosequence

\section{A B S T R A C T}

Global warming leads to deglaciations in high-elevation regions, which exposes deglaciated soils to microbial colonization. Disparity in year-to-year successional patterns of bacterial community and influencing factors in freshly deglaciated soils remain unclear. We explored the abundance of bacterial $16 \mathrm{~S}$ rRNA gene and community succession in deglaciated soils along a 14-year chronosequence after deglaciation using GPCR and Illumina sequencing on the Tibetan Plateau. The results showed that the abundance of bacterial 16S rRNA gene gradually increased with increasing deglaciation age. Soil bacterial community succession was clustered into three deglaciation stages, which were the early (zero-year old), transitional (1-7 years old) and late (8-14 years old) stages. A significantly abrupt bacterial community succession occurred from the early to the transitional stage $(P<0.01)$, while a mild succession $(P=0.078)$ occurred from the transitional to the late stage. The bacterial community at the early and transitional stages were dominated by Proteobacteria, while the late stage was dominated by Actinobacteria. Less abundant $(<10 \%)$ Acidobacteria, Gemmatimonadetes, Verrucomicrobia, Chloroflexi, Planctomycetes, unclassified bacteria dominantly occurred in the transition and late stage and Cyanobacteria in the early stage. Total organic carbon (24.7\%), post deglaciation age (21\%), $\mathrm{pH}(16.5 \%)$ and moisture $(10.1 \%)$ significantly contributed $(P<0.05)$ to the variation of bacterial community succession. Our findings provided a new insight that short time-scale chronosequence is a good model to study yearly resolution of microbial community succession.

(c) Higher Education Press 2020

\footnotetext{
* Corresponding author

E-mail address: wdkong@itpcas.ac.cn(W.D. Kong)
}

\section{Introduction}

Global warming has contributed to glacial retreat in both high elevation and high latitude regions over the past 100 years (Yao et al., 2012). Glaciers on the Tibetan Plateau (TP, above sea level $>4500 \mathrm{~m}$ ) that covering more than $100000 \mathrm{~km}^{2}$ (Kang et al., 2010), have been experiencing fast retreat in the 
last few decades due to warming (Yao et al., 2012). Glacier retreats expose a large mass of frequently oligotrophic deglaciated soils, which are rapidly colonized by pioneering microorganisms (Liu et al., 2016). A large pool of studies demonstrated that these pioneering microorganisms play a key role in elemental biogeochemical cycling and the accumulation of nutrients for plant establishment in the recently deglaciated soils (Bradley et al., 2014).

Microbial communities in deglaciated soils usually show clear succession patterns along a large timescale deglaciation chronosequence, ranging from dozens to thousands of years (Zumsteg et al., 2012). Past research has shown that in deglaciated soils microbial communities usually follow patterns of succession (Fierer et al., 2010). Cyanobacteria and Betaproteobacteria, for example, have been observed as particularly prominent in early succession (Zumsteg et al., 2012; Liu et al., 2016; Khan et al., 2019). Other studies have shown increases in the relative abundance of Alphaproteobacteria in later succession (Nemergut et al., 2007; Kim et al., 2017). Actinobacteria have been observed to show a stable trend along the whole profile of chronosequences, such as at the Tianshan No. 1 glacier, China (6-100 years) (Wu et al., 2012). However, shifts in bacterial community structure and compositions are dependent on geographical locations of the glacier and often times lack a consistent pattern along chronosequences at different sites (Bajerski and Wagner, 2013; Kim et al., 2017). A large body of studies on chronosequence soils has concentrated on long timescales from decades to millennia of soil development (Walker et al., 2010). Such research has included chronosequences that span hundreds if not thousands of years of soil development such chronosequences studied at Yukon, Canada $>200$ years (Kazemi et al., 2016) to the Franz Josef chronosequence in New Zealand which spans 120000 years (Jangid et al., 2013). However, as we increasingly come to understand that microbial succession is occurring on a shorter time-scale hence, yearly characterization of microbial community succession after glacier retreat remains unclear.

The aim of this study was to characterize the difference in the yearly shift of bacterial colonization, community succession and their driving environmental factors in freshly deglaciated soils on the TP using high throughput sequencing method. We hypothesized that the bacterial community succession exhibited a clear disparity pattern of colonizing on yearly basis in a short time-scale chronosequence, and their influencing factors would vary along the deglaciation chronosequence.

\section{Material and methods}

\subsection{Study site description and sampling}

The study site was at Muztag Ata glacier $\left(38^{\circ} 16^{\prime} \mathrm{N}, 75^{\circ} 0^{\prime} \mathrm{E}\right)$, whose glacier termini was $4350 \mathrm{~m}$ above sea level on the north-western TP. Muztag Ata glaciers are climatically controlled by mid-latitude westerlies, and the highest precipitation in the region occurs in summer. The glacier mass loss and retreating rate have been yearly monitored for the last decade, and glacier retreat rate was approximately $1 \mathrm{~m} \mathrm{year}^{-1}$ (Yao et al., 2012; Zhang et al., 2016). The deglaciated soil samples were collected in August 2015. Soil samples were collected from 15 sites along chronosequence using an ethanol-cleaned shovel to prevent contamination between samples. The surface soils $(0-5 \mathrm{~cm}$ depth) were randomly sampled in three replicates in sterile sampling bags (Labplas, Canada) every $1 \mathrm{~m}$ along an un-vegetated chronosequence from the glacier terminus. Thus the deglaciation chronosequence ranged from zero to 14 years. The soils sieved through a 2-mm mesh to remove stones and were transported to the laboratory in an icebox. Soils for DNA extraction were stored at $-80^{\circ} \mathrm{C}$ and the remaining samples were air-dried for physicochemical analysis.

\subsection{Soil physicochemical analysis}

Soil physicochemical factors were analyzed using standard methods (Tan, 2005). Soil moisture was gravimetrically determined after oven-drying at $105^{\circ} \mathrm{C}$ for $12 \mathrm{~h}$. Soil $\mathrm{pH}$ was measured in a 1:5 soil-to-water suspension using a $\mathrm{pH}$ meter (Sartorius PB-10, Germany). Total organic carbon (TOC) was measured in the solid state using a TOC analyzer (TOCVCPH, Shimadzu, Japan), while contents of total nitrogen (TN), total organic carbon (TC), total sulfur (TS), TC to TN ratio $(\mathrm{C} / \mathrm{N})$ were measured using elemental analyzer (vario MAX, elementar, Germany).

\subsection{DNA extraction, PCR and high-throughput sequencing}

Total DNA was extracted using the MO BIO Power Soil DNA extraction kit (Mo Bio Laboratories, Carlsbad, CA, USA) according to the manufacturer's instructions. The universal primer 515F (5'-GTGCCAGCMGCCGCGGTAA-3') and 909r (5'-GGACTACHVGGGTWTCTAAT-3') (Tuan et al., 2014) was used for Illumina MiSeq sequencing at the Chengdu Institute of Biology, Chinese Academy of Sciences.

\subsection{Quantification of genes}

16S rRNA gene was quantified using a specifically designed primer set 341F/534R (Liu et al., 2016), using a Light Cycler 480 (Roche diagnostics Ltd, USA). Each reaction was performed in $10 \mu \mathrm{L}$ reaction volume containing $5 \mu \mathrm{L}$ of SYBR Green Premix (Takara, Japan), $0.5 \mu \mathrm{L}$ each primer and $1 \mu \mathrm{L}$ template DNA. Quantitative PCR programs followed our previous study (Liu et al., 2016). The specificity of amplicons was checked using melting curve and agarose gel electrophoresis. The amplification efficiency of the target gene fragments was $>85 \%$.

\subsection{Illumina sequence data analysis}

Raw sequence data were processed using MOTHUR pipeline (v. 1.34.3) (Schloss et al., 2009). Paired-end reads were merged and sequences were quality screened with following 
settings: any sequences with length $<300$ or $>400$, more than 1 mismatches at the primer region, average quality $<35$, ambiguous bases $>0$ and homopolymer length $>9$ were removed for further analysis. The remaining sequences were aligned to Silva reference alignment (release 128), which was trimmed to the same region amplified, and those sequences that did not align were removed. Chimera sequences were screened using UCHIME (Edgar et al., 2011). The sequences were classified using Bayesian classifier against Silva database (release 128), with a minimum confidence score of 80\% (Wang et al., 2007). All Archaea, Eukaryota, chloroplasts, mitochondria and unknown sequences were culled. All sequences were classified into operational taxonomic units (OTUs) at $97 \%$ identity. The data sets were sub-sampled at an equal depth of 7230 , and with a coverage of the sequencing depth of 0.92. The Illumina sequences have been submitted in the National Center for Biotechnology Information (NCBI) Sequence Read Archive database (accession number, PRJNA503755).

\subsection{Statistical analysis}

Figures with fitting curves (Pearson's correlations) were generated using Sigma Plot 12.5 (Systat Software Inc., CA, USA). To determine the extents of soil physicochemical factors in explaining bacterial community variations, a distance-based redundancy analysis (dbRDA) plot was constructed using Canoco5 (Microcomputer Power, Ithaca, NY). Before RDA, the environemtal factors that passed the Monte Carlo permutation test $(P<0.05$ or VIF $<20)$ were counted for further analysis, and the forward selection in Canonoco was used to chose those significantly explaining factors (Guo et al., 2015). Difference of bacterial community structure between deglaciated soils was tested by permutational multivariate analysis of variance (PERMANOVA) using $R$. Heatmap was constructed using ClustVis (Metsalu and Vilo, 2015).

\section{Results}

\subsection{Abundance of 16S rRNA gene}

The 16S rRNA gene abundance linearly and significantly increased from young soils to old soils along the 14-year deglaciation chronosequence, ranging from $10^{8}$ to $10^{9}$ copies $\mathrm{g}^{-1}$ dry soils $(P<0.001$, Fig. 1$)$.

3.2 Bacterial community exhibited a three-stage succession along the short-time deglaciation chronosequence

The deglaciated soil bacterial community exhibited a gradual succession along the 14-year deglaciation chronosequence and was grouped into three separate stages based on their OTU profiles. Bacterial communities in young soils (zero-year old) grouped into an early deglaciation stage, those in 1- to 7 year old soils grouped into a transitional stage, and the 8- to 14-year old soils into a late stage (Fig. 2A). The differences of

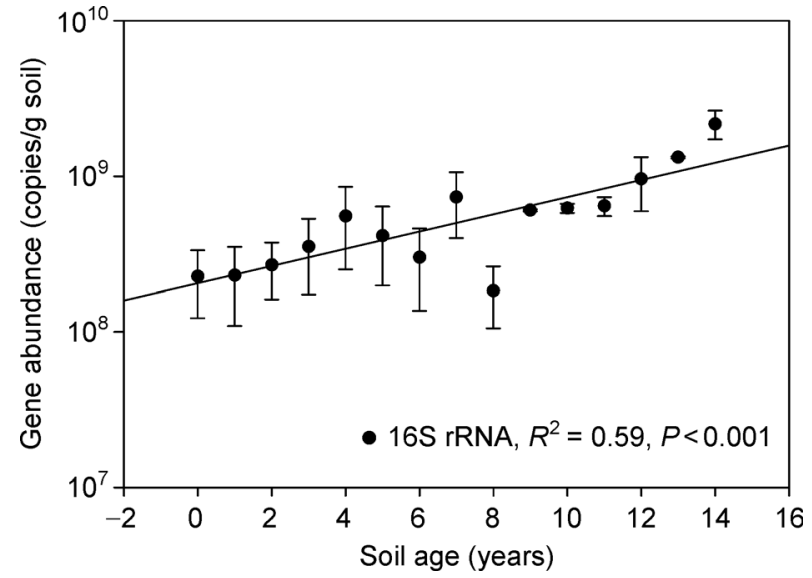

Fig. 1 Gene abundance of bacterial 16S rRNA along the 14year deglaciation chronosequence, the solid circles representing the average values.

bacterial community between the early and the other two stages (transitional/late) were all significant according to the PERMANOVA test $(P<0.001)$, while the difference between the transitional and late stages was not significant $(P=0.078)$. We further identified the dominant phyla at each succession stage by assessing their all OTUs at phylum-level profiles of the three succession stages. The results showed that the early stage was similar to the transitional stage, and different from the late stage than the OTU-level profiles (Fig. 2B). The early and transitional stage soils were dominated by Alphaand Betaproteobacteria, while the late stage soils were dominated by Actinobacteria.

\subsection{Key factors influencing the bacterial community succession}

According to the Monti Carlo permutation test; TOC, post deglaciation age, $\mathrm{pH}$ and soil moisture significantly explained the bacterial community structure. TOC contributed $24.3 \%$, post deglaciation age $21 \%, \mathrm{pH} 16.5 \%$ and moisture $10.1 \%$ $(P<0.05)$. At transitional stage soil, moisture significantly contributed $22.99 \%(P<0.05)$ and TOC showed contribution of $18.6 \%(P=0.07)$, in the late stage, post deglaciation age positively contributed $19.9 \%$ and soil moisture $18.2 \%$ $(P<0.01)$. While no significant contribution of environmental factors was found in the early stage (Table 1).

3.4 Annual dynamics of bacterial compositions along the chronosequence

A total of 39 bacterial phyla were identified in all the deglaciated soils and their relative abundances exhibited a clear annual change along the 14-year deglaciation chronosequence (Fig. 3). Proteobacteria exclusively dominated the bacterial communities in all soils, whose relative abundance accounted for $35 \%$ to $88.5 \%$ in the first 4 -year old soils and then substantially decreased to $40 \%$ at the late stage $\left(R^{2}=\right.$ $0.21, P<0.01$, Fig. 4). In contrast, Actinobacteria relative 
abundance was relatively stable $(<10 \%)$ in the first 5 -years, and then sharply increased to $24 \%$ in the 10 -year old soils $\left(R^{2}\right.$
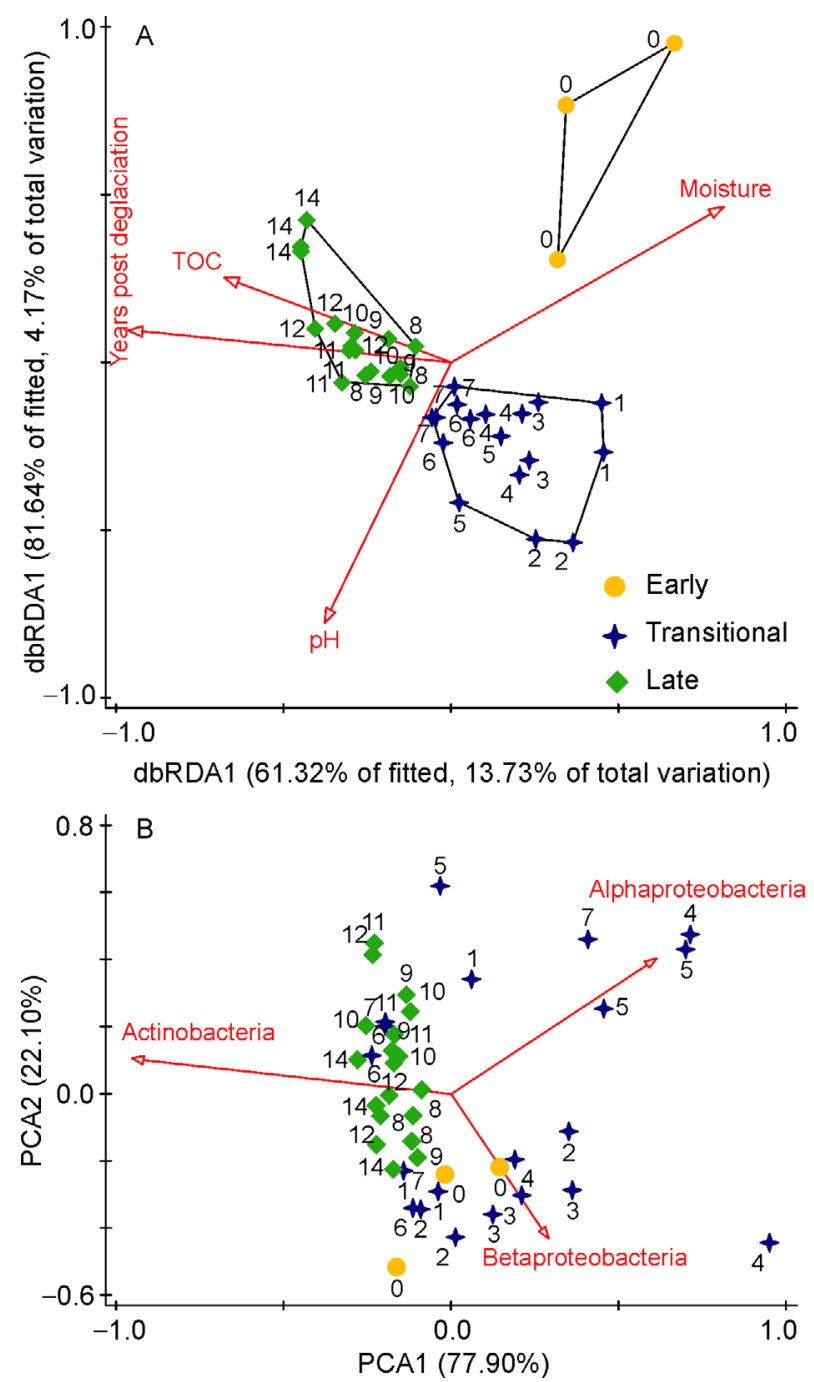

Fig. 2 The distance-based redundancy analysis (dbRDA) of bacterial community structure and relations with soil physicochemical factors and soil age based on the operational taxonomic unit level (A) and principal component analysis (PCA) of dominant bacteria phyla based on the phylum-level (B) in deglaciated soils on the Tibetan Plateau. TOC: total organic carbon.
$=0.32, P<0.001)$. Bacteroidetes kept stable during the 14year deglaciation chronosequence, approximately accounting for $15 \%$ in relative abundance. Proteobacteria consisted of Burkholderiales and Sphingomonadales, the Burkholderiales were dominantly composed by Polaromonas and showed a rapid decrease from $48 \%$ to $10 \%$, and the Sphingomonadales exhibited a slight decrease from $32 \%$ to $2 \%$ along the 14 years chronosequence (Fig. 5A). Actinobacteria comprised of order Acidimicrobiales and Actinomycetales, and both order significantly increased from $0.5 \%$ to $5 \%$ and from $8 \%$ to $20 \%$ along the chronosequence ( $P<0.05$, Fig. 5B), respectively. Bacteroidetes were dominated by order Cytophagales and Saprospirales, and both orders ranged from $0.05 \%$ to $16.2 \%$ and from $0.2 \%$ to $23.4 \%$, respectively (Fig. $5 \mathrm{C}$ ). Some bacterial communities were observed with a relative abundance of $>3 \%$ to $<10 \%$, such as the unclassified bacteria was abruptly increased from $0.5 \%$ to $9 \%$ in the first 2-year old soils, afterward ranged from $1 \%$ to $7 \%$ in relative abundance. The relative abundance of Acidobacteria kept fairly stable $(<3 \%)$ in the first 5 -year old soils and then slightly but significantly increased to $5 \%$ at a late stage $(P<0.001$, Supplementary Fig. S1A). The abundance of Gemmatimonadetes was $<2 \%$ in the first 5 -year old soils and then increased to around $4 \%$ in the late stage $(P<0.05)$. Similarly, the abundance of Verrucomicrobia was $<1.5 \%$ in the first 5 -year old soils, and thereafter significantly increased to $3 \%$ in late stage $(P<0.001$, Supplementary Fig. S1B). Cyanobacteria sharply increased from $1.5 \%$ to $6 \%$ to first year and then remained approximately $1 \%$ along the remaining chronosequence (Fig. S1B). Chloroflexi and Planctomycetes were significantly increased ranging from $0.5 \%$ to $8 \%$ and from $0.5 \%$ to $3 \%$, respectively $(P<0.001)$. The relative abundance of the remaining bacterial phyla were less than $1 \%$. Heatmap further elaborated that Proteobacteria highly influenced the initial deglaciated soils (7-year old), and Actinobacteria, Verrucomicrobia, Acidobacteria, Planctomycetes influenced the old soils (8- to 14-year, supplementary Fig. S2).

\section{Discussion}

Our study was along a 14-year chronosequence after glacier retreat, offering an opportunity to understand the short-term, inter-year disparity in succession of pioneering bacteria and their influencing factors in the deglaciated barren soils on the

Table 1 Contribution of each environmental factor influencing bacterial community variation along the entire chronosequence and at the three deglaciation stages.

\begin{tabular}{|c|c|c|c|c|}
\hline \multirow[t]{2}{*}{ Soil factors } & \multicolumn{4}{|c|}{ Contribution \% } \\
\hline & Entire chronosequence & Early stage & Transitional stage & Late stage \\
\hline TOC & $24.7^{*}$ & - & 18.6 & \\
\hline Post deglaciation age & $21^{* *}$ & - & - & $19.9^{*}$ \\
\hline $\mathrm{pH}$ & $16.5^{*}$ & & & \\
\hline Moisture & $10.1^{* *}$ & - & $22.2^{*}$ & $18.2^{*}$ \\
\hline Total explained (\%) & 22.99 & & 24.57 & 26.65 \\
\hline
\end{tabular}

-: without significant contribution. TOC: total organic carbon. ${ }^{*} P<0.05,{ }^{* *} P<0.01$. 


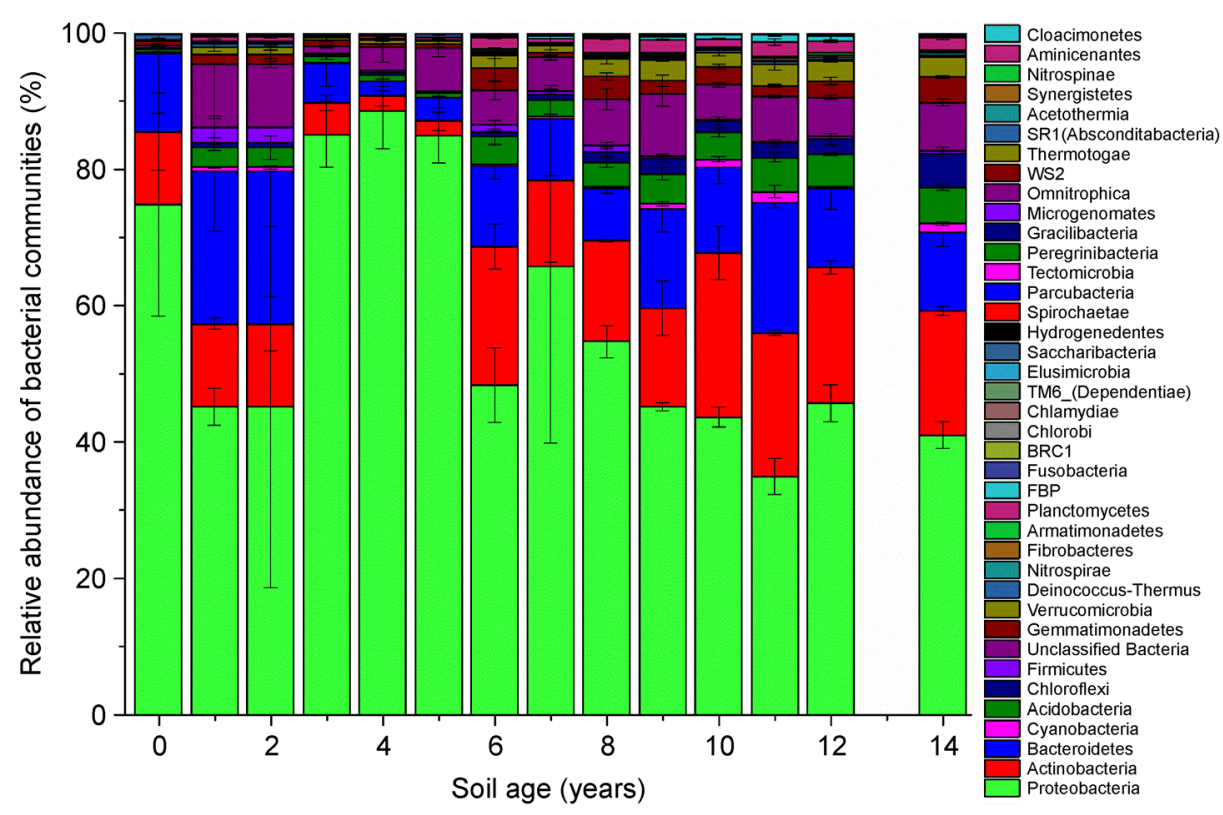

Fig. 3 The shift of bacterial communities composition along the 14-year deglaciation chronosequence.

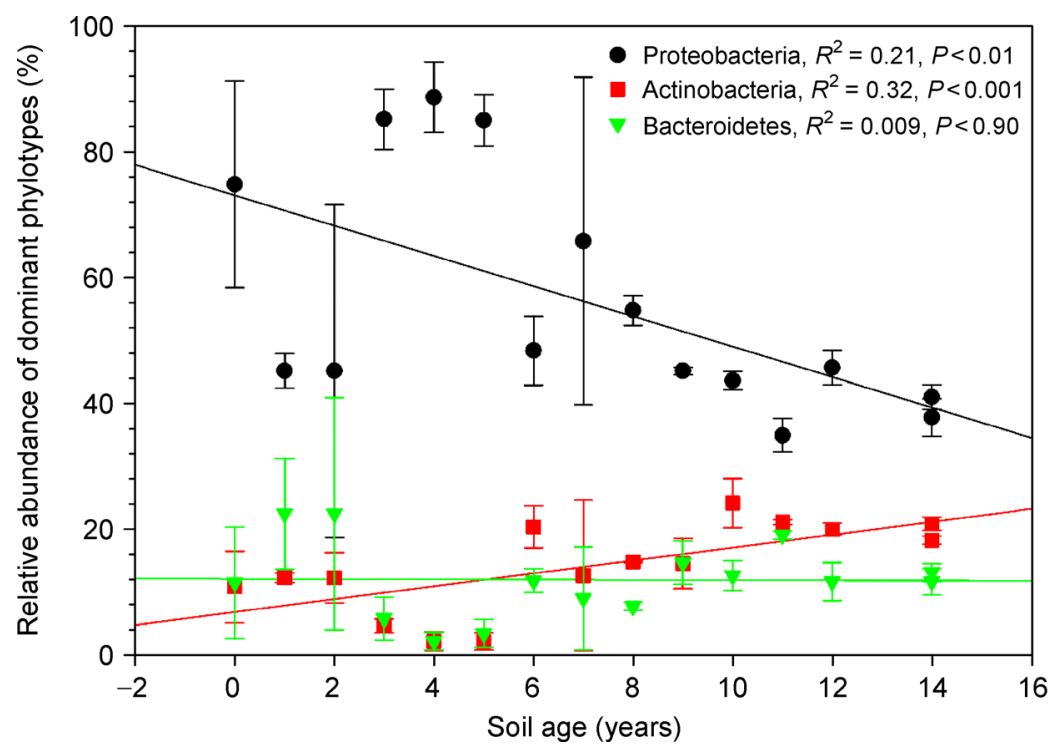

Fig. 4 Yearly change in relative abundance of dominant bacterial phyla in deglaciated soils along the deglaciation chronosequence on the Tibetan Plateau.

TP. Our result of bacterial 16S rRNA gene abundance demonstrated that bacterial communities abundantly colonized young deglaciated soils, increased gradually with slight fluctuations from zero-year to 14-year old soils (Fig. 1). These findings are in accordance with that bacterial 16S rRNA gene abundance, increased with deglaciation soil age of TP glaciers (10-year old) (Liu et al., 2016). Similarly, in Peru deglaciated soils an increase in Phylotype abundance (abundance of microbial population) was observed from young soils to old soils (20-year old) (Nemergut et al., 2007). Interestingly, bacterial phylogenetic composition of this study site is largely different than that of southern TP deglaciated soils studied previously (Liu et al., 2016). In our study, Proteobacteria was the dominant community, while southern TP deglaciated soils were dominated by autotrophic Cyanobacteria (Liu et al., 2016). We assume that the above heterogeneity of bacterial colonization in the TP Plateau could be related to a few reasons. First, the thermodynamics of glaciers as the Muztag Ata glaciers are retreating around $1 \mathrm{~m}$ year $^{-1}$ and southern TP glaciers (e.g., Zhadang glacier) 10 m year $^{-1}$ (Yao et al., 2012; Liu et al., 2016). Global warming cause glaciers melt and disappear, which seriously affected the microbial community colonizing them (Zeng et al., 2013). Climat change is altering the basal temperature of the ice, 

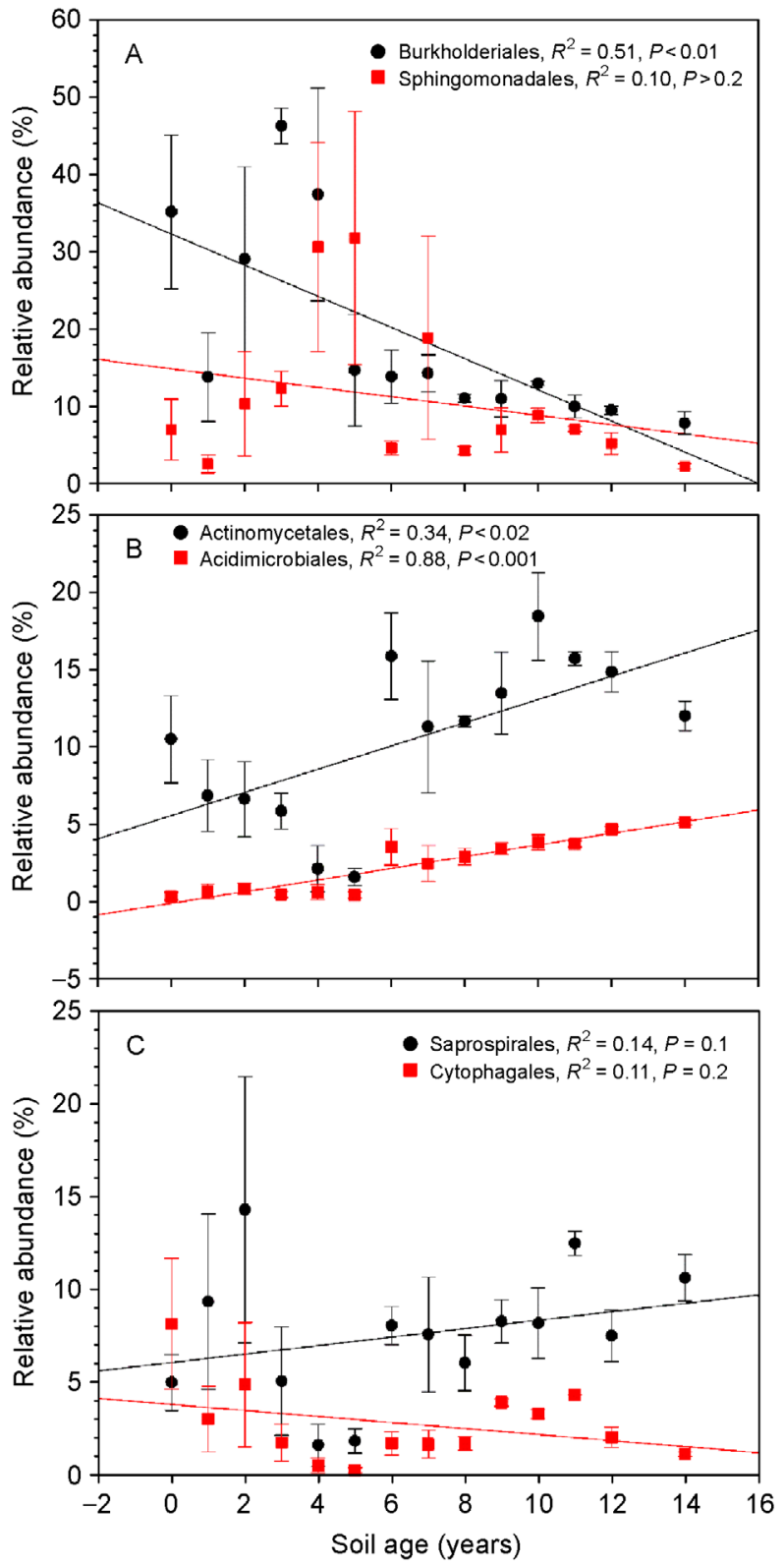

Fig. 5 Yearly change in relative abundance of dominant bacterial orders of Proteobacteria (A), Actinobacteria (B) and Bacteroidetes $(C)$ in deglaciated soils along the deglaciation chronosequence on the Tibetan Plateau..

change it from cold to polythermal, which facilitates the arrival of new microbial communities that are not psychrophiles but mesophiles hence bringing changes in the diversity and composition of microbial communities (Hell et al., 2013; Nowak and Hodson, 2014). Further the marine ecosystem influence, where the Muztag Ata glaciers are westerly influenced glaciers and southern TP glaciers are monsoon influenced (Holzer et al., 2015; Yao et al., 2012). In Wanda deglaciated soils some of the phylotypes were related to marine microbial communities, which showed the impact of marin environment on the composition of chronosequence microbiome (Pessi et al., 2015). Studies have found that the composition of snow microorganisms depend on the proximity to the sea (Stibal et al., 2015). In Antarctic glacier snow some species of Alphaproteobacteria Bacteroidetes and Cyanobacteria were from marine environments (Stibal et al., 2015). Additionally, different types and levels of nutrients from various sources such as adjacent supraglacial and subglacial environments, precipitation and aerial deposition, mammals and birds droppings (Bradley et al., 2014) are likely to be responsible in bacterial colonizing in a heterogeneous manner in the distant deglaciated soils of the same TP plateau.

Bacterial community succession fell into three deglaciation stages, the early stage (zero-year old), the transitional stage (1- to 7-year old) and the late stage (8- to 14-year old). The clear separation of early bacterial succession from transitional and late stages could be due to various reasons. Such as the early stage soil was exactly collected from the glacier tongue, and that the bacterial community could be derived from subglacial and/or glacial environment as observed by a previous study (Bradley et al., 2016). While the discrimination in the transitional and late stages for more or less could be due to soil physicochemical factors and among microbial interaction. Because the current study site consisted of bare soils with no vegetation, therefore the above soil factors could influence bacterial community structures in chronosequence as opposed to plant influence as well. The abrupt succession occurred from the early to the transitional stage at both OTU and phylum levels, while the succession from the transitional to the late stage was mild, particularly at the phylum-level (Fig. 2B). The bacterial community structures change within the chronosequence due to physicochemical parameters and plant colonization (Knelman et al., 2012; Zumsteg et al., 2012; Brown and Jumpponen, 2014). Within the short time-scale chronosequence, besides physical factors, chemical composition of bedrock plays vital role in bacterial community structural change (Khan et al., 2019). Oligotrophic soils (deficient for carbon and nitrogen resources) select specific bacterial communities, specifically carbon and nitrogen fixers (Crews et al., 2001; Stibal et al., 2008) and bacterial community related to weathering can survive here (Frey et al., 2010). In the current study site besides oligotrophic conditions very low abundance of photoautotrophs and huge abundance of weathering bacteria were observed, particularly in the early stage. We assume that the lower abundance of photoautotrophs could be due to the low level of sunlight received by this deglaciation chronosequence. On the other hand, the increase of TOC and heterotrophic Actinobacterial abundance suggested that nutrients enrichment in soil (through atmospheric deposition and autochthonous sources) along with chronosequence age, bacterial communities that utilize carbon and nitrogen appear and may outcompete those bacteria that are successful in nutrient deficient soils (Schüette et al., 2010; Zumsteg et al., 2012). Thus, different bacteria prefer colonizing different minerals/nutrients, which displayed change in community structure along the chronosequence. Our previous study showed that microbes could rapidly 
colonize and inhabit deglaciated soils, despite harsh environments, such as high UV radiation, drought, large fluctuations of daily and seasonal temperature and lack of nutrients (Liu et al., 2016). Previously, the three-stage microbial community succession was observed in long-term chronosequences of deglaciated soils, such as 136-year (Zumsteg et al., 2012) and > 229-year (Jangid et al., 2013).

Our results revealed that TOC, post deglaciation age, $\mathrm{pH}$ and moisture played a key role in shifting the bacterial community succession in the 14-year chronosequence scale, although these bacteria are exposed to a series of environmental stresses. Various studies have determined the predominant role of post deglaciation age (Nemergut et al., 2007; Noll and Wellinger, 2008) soil pH, carbon (Zumsteg et al., 2012; Kim et al., 2017; Yoshitakea et al., 2018) and moisture (Pessi et al., 2019) driving bacterial community structure in deglaciated soils. In the transition deglaciation stage, soil factors such as moisture and TOC were dominant in the bacterial community succession, indicating that the microbial colonization was coinciding with the substantial change of soil physicochemical factors. While, bacterial community succession at the late stage was significantly influenced by soil age and soil moisture. This revealed that microbial characteristics (or microbial interactions) and other unmeasured environmental factors supplemented changes in bacterial community succession (Bajerski and Wagner, 2013; Bradley et al., 2014). In contrast, in the early stage no factors indicated significant contribution in bacterial successions, however, $\mathrm{C} / \mathrm{N}$ and moisture were found to be the major factors without significantly influencing bacterial community. The occurrence of huge abundance of chemotrophs in the early stage was evident that this community could probably be the potential user of recalcitrant/autocthonous carbon and nitrogen contents. In Antarctic mineral soils, the availability of nutrients and water was observed to greatly affect microbial community structure (Wynn-Williams, 1996; Yergeau et al., 2012). A study along a 140-year deglaciation chronosequence showed that microbial community succession was driven by diverse factors, such as soil age, soil carbon and nitrogen, contents and plant coverage (Zumsteg et al., 2012). Similarly, deglaciated soils of the Austre Lovénbreen glacier, Svalbard (High Arctic), $\mathrm{pH}$ and soil temperature played major roles in shaping bacterial community structure over the course of succession (Kim et al., 2017). Collectively, after glacier recession, temporal heterogeneity, landscape mineralogy, ancient subglacial environment, autochthonous production, aeolian, external biological (birds and animals) and supraglacial inputs exert significant control on the microbial community structure (Bradley et al., 2014). These findings signify that soil age of a chronosequence provides comprehensive information about microbial colonization and community succession, their response to environmental factors, and activity (i.e., biogeochemical cycling and soil development).

Proteobacteria, Actinobacteria, and Bacteroidetes dominated all deglaciated soils in the current study, in agreement with Alps region (Philippot et al., 2011). These bacteria were frequently observed worldwide in both terrestrial and aquatic ecosystems (Janssen, 2006; Pessi et al., 2015), Himalayan Mountains (Srinivas et al., 2011) and the Andes (Nemergut et al., 2007). Interestingly, very less population of Cyanobacteria (almost $1 \%$ on average) was observed in the current deglaciated soils. These findings revealed that the TP deglaciated soils are highly heterogeneous in terms of colonizing bacterial community. Because, its southern deglaciated soils (Zhadang glacier) were dominated by photoautotrophs (Cyanobacteria) (Liu et al., 2016), and its eastern deglaciated soils (Hailuogou glacier) indicated high abundance of chemotrophs (Proteobacteria and Acidobacteria) (Jiang et al., 2019). Proteobacteria, accounting for up to $81.3 \%$ in relative abundance in the early stage soils substantially decreased to $40 \%$ in the late stage soils (Fig. 4), and composed of Burkholderiales and Sphingomonas (Fig. 5A). Burkholderiales, particularly Polarmonoas, were frequently observed in glacial ice core and subglacial environments (Skidmore et al., 2000; Sheridan et al., 2003) and high-elevation environments (Bowers et al., 2009). Burkholderiales were effective rock-weathering bacteria with high pH tolerance (Ma et al., 2012; Stopnisek et al., 2014), and could harbor debris-rich basal ice (Montross et al., 2014) and deglaciated soils (Liu et al., 2016).

Actinobacteria linearly increased along the chronosequence (Fig. 4), in agreement with the enhanced Actinobacteria abundance along the increasing distance from a glacier in Antarctica (Bajerski and Wagner, 2013). An opposite pattern was observed for Actinobacteria along the chronosequence soils of Damma glacier (Zumsteg et al., 2012). Actinobacteria were also reported to be relatively stable along chronosequences in Austrian Alps and Tianshan mountains No. 1 glacier in China (Wu et al., 2012; Philippot et al., 2011). The predominant occurrence of Actinobacteria in extreme environments could be due to several reasons. They usually form spores that can disperse easily and their several members (e.g., Actinomycetales) could even grow at or below $0^{\circ} \mathrm{C}$ (Babalola et al., 2009; Rhodes et al., 2013). They have hyphae that allow them to reach water and nutrients in pores further away (Barka et al., 2015). Actinobacteria are able to degrade recalcitrant organic matters, such as lignin (Heuer et al., 1997), dead microbes, fungal spores and pollens (Huelsenbeck and Ronquist, 2001; Hawes, 2008; Pearce et al., 2009). Additionally, some Actinobacteria could oxidize carbon monoxide, dimethyl sulfide and air $\mathrm{H}_{2}$ for energy to fix $\mathrm{CO}_{2}$ in soils (Reichert et al., 1998; Lynch et al., 2012). The high metabolic versatility thus could benefit Actinobacteria to survive the harsh environments on the TP. The high dominance of Betaproteobacteria in the early stage soils in the current study suggested that they may partly originate from the glacial environments. Evidently, many studies frequently observed a higher proportion of Betaproteobacteria in environments, like glacier surface, glacial ice core and subglacial environments (Skidmore et al., 2000; Sheridan et al., 2003; Philippot et al., 2011). Bacteroidetes were also frequently detected in deglaciated soils and cold and poorly 
developed soils (Liebner et al., 2008; Ganzert et al., 2011; Wu et al., 2012; Bajerski and Wagner, 2013; Kim et al., 2017). Bacteroidetes could degrade a wide range of organic polymers (Buckley and Schmidt, 2001), and numerous isolates produce extracellular enzymes such as lipases, proteases and phosphatases (Aislabie et al., 2006). Thus, Bacteroidetes may be get involved in initial soil formation, particularly in the development of deglaciated soils (Aislabie et al., 2006).

\section{Conclusions}

Our study found that the bacterial communities along the 14year deglaciation chronosequence fell into three stages. TOC, soil age, $\mathrm{pH}$ and moisture played a key role in explaining the bacterial community succession at the 14-year chronosequence scale. The population of bacterial community (abundance of 16S rRNA gene) increased with deglaciation age progression. The early stage bacterial community was enriched in Proteobacteria, and Actinobacteria dominantly occurred in transition and late stages. Some less abundant (<10\%) Acidobacteria, Gemmatimonadetes, Verrucomicrobia, Chloroflexi, Planctomycetes and unclassified bacteria were dominantly observed in the transition and late stages, and Cyanobacteria substantially occurred from early to transition stage. Burkholderiales and Sphingomonadaceaes related to Proteobaccteria and Acidimicrobiales and Actinomycetales related to Actinobacteria constituted a large portion of communities.

\section{Conflict of interest}

The authors declare no conflict of interest.

\section{Acknowledgments}

This work was supported by the Chinese Academy of Sciences (QYZDB-SSW-DQC033, KZZD-EW-TZ-14 and XDA20050101) and the National Natural Science Foundation of China (41471054 and 41525002). We thank the Muztagh Ata Station for Westerlies Environment Observation and Research, Chinese Academy of Sciences, for logistic support and sampling assistance.

\section{Electronic supplementary material}

Supplementary material is available in the online version of this article at http://dx.doi.org/10.1007/s42832-020-0027-5 and is accessible for authorized users.

\section{References}

Aislabie, J.M., Chhour, K.L., Saul, D.J., Miyauchi, S., Ayton, J., Paetzold, R.F., Balks, M.R., 2006. Dominant bacteria in soils of Marble point and Wright valley, Victoria land, Antarctica. Soil Biology \& Biochemistry 38, 3041-3056.
Babalola, O.O., Kirby, B.M., Le Roes-Hill, M., Cook, A.E., Cary, S.C., Burton, S.G., Cowan, D.A., 2009. Phylogenetic analysis of actinobacterial populations associated with Antarctic Dry Valley mineral soils. Environmental Microbiology 11, 566-576.

Bajerski, F., Wagner, D., 2013. Bacterial succession in Antarctic soils of two glacier forefields on Larsemann Hills, East Antarctica. FEMS Microbiology Ecology 85, 128-142.

Barka, E.A., Vatsa, P., Sanchez, L., Gaveau-Vaillant, N., Jacquard, C., Meier-Kolthoff, J.P., Klenk, H.P., Clément, C., Ouhdouch, Y., van Wezel, G.P., 2015. Taxonomy, physiology, and natural products of Actinobacteria. Microbiology and Molecular Biology Reviews 80, $1-43$.

Bowers, R.M., Lauber, C.L., Wiedinmyer, C., Hamady, M., Hallar, A. G., Fall, R., Knight, R., Fierer, N., 2009. Characterization of airborne microbial communities at a high-elevation site and their potential to act as atmospheric ice nuclei. Applied and Environmental Microbiology 75, 5121-5130.

Bradley, J.A., Arndt, S., Šabacká, M., Benning, L.G., Barker, G.L., Blacker, J.J., Yallop, M.L., Wright, K.E., Bellas, C.M., Telling, J., Tranter, M., Anesio, A.M., 2016. Microbial dynamics in a HighArctic glacier forefield: a combined field, laboratory, and modelling approach. Biogeosciences 13, 5677-5696.

Bradley, J.A., Singarayer, J.S., Anesio, A.M., 2014. Microbial community dynamics in the forefield of glaciers. Proceedings. Biological Sciences 281, 9.

Brown, S.P., Jumpponen, A., 2014. Contrasting primary successional trajectories of fungi and bacteria in retreating glacier soils. Molecular Ecology 23, 481-497.

Buckley, D.H., Schmidt, T.M., 2001. The structure of microbial communities in soil and the lasting impact of cultivation. Microbial Ecology 42, 11-21.

Crews, T.E., Kurina, L.M., Vitousek, P.M., 2001. Organic matter and nitrogen accumulation and nitrogen fixation during early ecosystem development in Hawaii. Biogeochemistry 52, 259-279.

Edgar, R.C., Haas, B.J., Clemente, J.C., Quince, C., Knight, R., 2011. UCHIME improves sensitivity and speed of chimera detection. Bioinformatics (Oxford, England) 27, 2194-2200.

Fierer, N., Nemergut, D., Knight, R., Craine, J.M., 2010. Changes through time: integrating microorganisms into the study of succession. Research in Microbiology 161, 635-642.

Frey, B., Rieder, S.R., Brunner, I., Plötze, M., Koetzsch, S., Lapanje, A., Brandl, H., Furrer, G., 2010. Weathering-associated bacteria from the Damma glacier forefield: physiological capabilities and impact on granite dissolution. Applied and Environmental Microbiology 76, 4788-4796.

Ganzert, L., Lipski, A., Hubberten, H.W., Wagner, D., 2011. The impact of different soil parameters on the community structure of dominant bacteria from nine different soils located on Livingston Island, South Shetland Archipelago, Antarctica. FEMS Microbiology Ecology 76, 476-491.

Guo, G., Kong, W., Liu, J., Zhao, J., Du, H., Zhang, X., Xia, P., 2015. Diversity and distribution of autotrophic microbial community along environmental gradients in grassland soils on the Tibetan Plateau. Applied Microbiology and Biotechnology 99, 8765-8776.

Hawes, T., 2008. Aeolian fallout on recently deglaciated terrain in the high Arctic. Polar Biology 31, 295-301. 
Hell, K., Edwards, A., Zarsky, J., Podmirseg, S.M., Girdwood, S. Pachebat, J.A., Insam, H., Sattler, B., 2013. The dynamic bacterial communities of a melting High Arctic glacier snowpack. ISME Journal 7, 1814-1826.

Heuer, H., Krsek, M., Baker, P., Smalla, K., Wellington, E.M., 1997. Analysis of actinomycete communities by specific amplification of genes encoding $16 \mathrm{~S}$ rRNA and gel-electrophoretic separation in denaturing gradients. Applied and Environmental Microbiology 63 , 3233-3241.

Holzer, N., Vijay, S., Yao, T., Xu, B., Buchroithner, M., Bolch, T., 2015. Four decades of glacier variations at Muztagh Ata (eastern Pamir): a multi-sensor study including Hexagon $\mathrm{KH}-9$ and Pléiades data. Cryosphere 9, 2071-2088.

Huelsenbeck, J.P., Ronquist, F., 2001. MRBAYES: Bayesian inference of phylogenetic trees. Bioinformatics (Oxford, England) 17, 754-755.

Jangid, K., Whitman, W.B., Condron, L.M., Turner, B.L., Williams, M. A., 2013. Soil bacterial community succession during long-term ecosystem development. Molecular Ecology 22, 3415-3424.

Janssen, P.H., 2006. Identifying the dominant soil bacterial taxa in libraries of 16S rRNA and 16S rRNA genes. Applied and Environmental Microbiology 72, 1719-1728.

Jiang, Y., Song, H., Lei, Y., Korpelainen, H., Li, C., 2019. Distinct cooccurrence patterns and driving forces of rare and abundant bacterial subcommunities following a glacial retreat in the eastern Tibetan Plateau. Biology and Fertility of Soils 55, 351-364.

Kang, S., Xu, Y., You, Q., Flügel, W.A., Pepin, N., Yao, T., 2010. Review of climate and cryospheric change in the Tibetan Plateau. Environmental Research Letters 5, 015101.

Kazemi, S., Hatam, I., Lanoil, B., 2016. Bacterial community succession in a high-altitude subarctic glacier foreland is a threestage process. Molecular Ecology 25, 5557-5567.

Khan, A., Kong, W., Muhammad, S., Wang, F., Zhang, G., Kang, S., 2019. Contrasting environmental factors drive bacterial and eukaryotic community successions in freshly deglaciated soils. FEMS Microbiology Letters 366, fnz229.

Kim, M., Jung, J.Y., Laffly, D., Kwon, H.Y., Lee, Y.K., 2017. Shifts in bacterial community structure during succession in a glacier foreland of the High Arctic. FEMS Microbiology Ecology 93, fiw213.

Knelman, J.E., Legg, T.M., O'Neill, S.P., Washenberger, C.L., González, A., Cleveland, C.C., Nemergut, D.R., 2012. Bacterial community structure and function change in association with colonizer plants during early primary succession in a glacier forefield. Soil Biology \& Biochemistry 46, 172-180.

Liebner, S., Harder, J., Wagner, D., 2008. Bacterial diversity and community structure in polygonal tundra soils from Samoylov Island, Lena Delta, Siberia. International Microbiology 11, 195 202.

Liu, J., Kong, W., Zhang, G., Khan, A., Guo, G., Zhu, C., Wei, X., Kang, S., Morgan-Kiss, R.M., 2016. Diversity and succession of autotrophic microbial community in high-elevation soils along deglaciation chronosequence. FEMS Microbiology Ecology 92, fiw160.

Lynch, R., King, A., Farías, M.E., Sowell, P., Vitry, C., Schmidt, S., 2012. The potential for microbial life in the highest-elevation
( $>6000 \mathrm{~m}$ a.s.I.) mineral soils of the Atacama region. Journal of Geophysical Research. Biogeosciences 117, G02028.

Ma, J., Wang, Y., Zhao, Y., Jin, X., Ning, N., Edmunds, W.M., Zhou, X., 2012. Spatial distribution of chloride and nitrate within an unsaturated dune sand of a cold-arid desert: Implications for paleoenvironmental records. Catena 96, 68-75.

Metsalu, T., Vilo, J., 2015. ClustVis: a web tool for visualizing clustering of multivariate data using Principal Component Analysis and heatmap. Nucleic Acids Research 43, W566-70.

Montross, S., Skidmore, M., Christner, B., Samyn, D., Tison, J.L., Lorrain, R., Doyle, S., Fitzsimons, S., 2014. Debris-rich basal ice as a microbial habitat, Taylor Glacier, Antarctica. Geomicrobiology Journal 31, 76-81.

Nemergut, D.R., Anderson, S.P., Cleveland, C.C., Martin, A.P., Miller, A.E., Seimon, A., Schmidt, S.K., 2007. Microbial community succession in an unvegetated, recently deglaciated soil. Microbial Ecology 53, 110-122.

Noll, M., Wellinger, M., 2008. Changes of the soil ecosystem along a receding glacier: Testing the correlation between environmental factors and bacterial community structure. Soil Biology \& Biochemistry 40, 2611-2619.

Nowak, A., Hodson, A., 2014. Changes in meltwater chemistry over a 20-year period following a termal regime switch from polythermal to cold-based glaciation at Austre Broggerbreen, Svalbard. Polar Research 33, 22779.

Pearce, D.A., Bridge, P.D., Hughes, K.A., Sattler, B., Psenner, R., Russell, N.J., 2009. Microorganisms in the atmosphere over Antarctica. FEMS Microbiology Ecology 69, 143-157.

Pessi, I.S., Pushkareva, E., Lara, Y., Borderie, F., Wilmotte, A., Elster, J., 2019. Marked succession of cyanobacterial communities following glacier retreat in the High Arctic. Microbial Ecology 77, 136-147.

Pessi, I.S., Osorio-Forero, C., Gálvez, E.J., Simões, F.L., Simões, J. C., Junca, H., Macedo, A.J., 2015. Distinct composition signatures of archaeal and bacterial phylotypes in the Wanda Glacier forefield, Antarctic Peninsula. FEMS Microbiology Ecology 91, 110.

Philippot, L., Tscherko, D., Bru, D., Kandeler, E., 2011. Distribution of high bacterial taxa across the chronosequence of two alpine glacier forelands. Microbial Ecology 61, 303-312.

Reichert, K., Lipski, A., Pradella, S., Stackebrandt, E., Altendorf, K., 1998. Pseudonocardia asaccharolytica sp. nov. and Pseudonocardia sulfidoxydans sp. nov., two new dimethyl disulfide-degrading actinomycetes and emended description of the genus Pseudonocardia. International Journal of Systematic and Evolutionary Microbiology 48, 441-449.

Rhodes, M., Knelman, J., Lynch, R.C., Darcy, J.L., Nemergut, D.R., Schmidt, S.K., 2013. Alpine and Arctic Soil Microbial Communities. In: Rosenberg, E., DeLong, E.F., Lory, S., Stackebrandt, E., Thompson, F., eds. The Prokaryotes. Springer, Berlin, Heidelberg pp. 43-55.

Schloss, P.D., Westcott, S.L., Ryabin, T., Hall, J.R., Hartmann, M., Hollister, E.B., Lesniewski, R.A., Oakley, B.B., Parks, D.H., Robinson, C.J., Sahl, J.W., Stres, B., Thallinger, G.G., Van Horn, D.J., Weber, C.F., 2009. Introducing mothur: open-source, platform-independent, community-supported software for describing 
and comparing microbial communities. Applied and Environmental Microbiology 75, 7537-7541.

Schmidt, S.K., Costello, E.K., Nemergut, D.R., Cleveland, C.C., Reed, S.C., Weintraub, M.N., Meyer, A.F., Martin, A.M., 2007. Biogeochemical consequences of rapid microbial turnover and seasonal succession in soil. Ecology 88, 1379-1385.

Schütte, U.M., Abdo, Z., Foster, J., Ravel, J., Bunge, J., Solheim, B., Forney, L.J., 2010. Bacterial diversity in a glacier foreland of the high Arctic. Molecular Ecology 19, 54-66.

Sheridan, P.P., Miteva, V.I., Brenchley, J.E., 2003. Phylogenetic analysis of anaerobic psychrophilic enrichment cultures obtained from a greenland glacier ice core. Applied and Environmental Microbiology 69, 2153-2160.

Skidmore, M.L., Foght, J.M., Sharp, M.J., 2000. Microbial life beneath a high arctic glacier. Applied and Environmental Microbiology 66, 3214-3220.

Srinivas, T.N.R., Singh, S.M., Pradhan, S., Pratibha, M.S., Kishore, K. H., Singh, A.K., Begum, Z., Prabagaran, S.R., Reddy, G.S.N., Shivaji, S., 2011. Comparison of bacterial diversity in proglacial soil from Kafni Glacier, Himalayan Mountain ranges, India, with the bacterial diversity of other glaciers in the world. Extremophiles 15 , 673-690.

Stibal, M., Tranter, M., Benning, L.G., Rehák, J., 2008. Microbial primary production on an Arctic glacier is insignificant in comparison with allochthonous organic carbon input. Environmental Microbiology 10, 2172-2178.

Stibal, M., Gözdereliler, E., Cameron, K.A., Box, J.E., Stevens, I.T., Gokul, J.K., Schostag, M., Zarsky, J.D., Edwards, A., Irvine-Fynn, T.D., Jacobsen, C.S., 2015. Microbial abundance in surface ice on the Greenland Ice Sheet. Frontiers in Microbiology 6, 225.

Stopnisek, N., Bodenhausen, N., Frey, B., Fierer, N., Eberl, L., Weisskopf, L., 2014. Genus-wide acid tolerance accounts for the biogeographical distribution of soil Burkholderia populations. Environmental Microbiology 16, 1503-1512.

Tan, K.H., 2005. Soil Sampling, Preparation and Analysis. CRC Press, Boca Raton.

Tuan, N.N., Chang, Y.C., Yu, C.P., Huang, S.L., 2014. Multiple approaches to characterize the microbial community in a thermophilic anaerobic digester running on swine manure: a case study. Microbiological Research 169, 717-724.

Walker, L.R., Wardle, D.A., Bardgett, R.D., Clarkson, B.D., 2010. The use of chronosequences in studies of ecological succession and soil development. Journal of Ecology 98, 725-736.

Wang, Q., Garrity, G.M., Tiedje, J.M., Cole, J.R., 2007. Naive Bayesian classifier for rapid assignment of rRNA sequences into the new bacterial taxonomy. Applied and Environmental Microbiology 73, 5261-5267.

Wu, X., Zhang, W., Liu, G., Yang, X., Hu, P., Chen, T., Zhang, G., Li, Z., 2012. Bacterial diversity in the foreland of the Tianshan No. 1 glacier, China. Environmental Research Letters 7, 014038.

Wynn-Williams, D., 1996. Antarctic microbial diversity: the basis of polar ecosystem processes. Biodiversity and Conservation 5, 1271-1293.

Yan, W., Ma, H., Shi, G., Li, Y., Sun, B., Xiao, X., Zhang, Y., 2017. Independent shifts of abundant and rare bacterial populations across East Antarctica Glacial Foreland. Frontiers in Microbiology 8, 1534.

Yao, T., Thompson, L., Yang, W., Yu, W., Gao, Y., Guo, X., Yang, X., Duan, K., Zhao, H., Xu, B., Pu, J., Lu, A., Xiang, Y., Kattel, D.B., Joswiak, D., 2012. Different glacier status with atmospheric circulations in Tibetan Plateau and surroundings. Nature Climate Change 2, 663-667.

Yergeau, E., Bokhorst, S., Kang, S., Zhou, J., Greer, C.W., Aerts, R., Kowalchuk, G.A., 2012. Shifts in soil microorganisms in response to warming are consistent across a range of Antarctic environments. ISME Journal 6, 692-702.

Yoshitakea, S., Uchidab, M., limurac, Y., Ohtsukad, T., Nakatsubo, T., 2018. Soil microbial succession along a chronosequence on a High Arctic glacier foreland, Ny-Ålesund, Svalbard: 10 years' change. Polar Science 16, 59-67.

Zhang, Z., Liu, S., Wei, J., Xu, J., Guo, W., Bao, W., Jiang, Z., 2016. Mass change of glaciers in muztag Ata-Kongur Tagh, Eastern Pamir, China from 1971/76 to $2013 / 14$ as derived from remote sensing data. PLoS One 11, e0147327.

Zeng, Y.X., Yan, M., Yu, Y., Li, H.R., He, J.F., Sun, K., Zhang, F., 2013. Diversity of bacteria in surface ice of Austre Lovénbreen glacier, Svalbard. Archives of Microbiology 195, 313-322.

Zumsteg, A., Luster, J., Göransson, H., Smittenberg, R.H., Brunner, I., Bernasconi, S.M., Zeyer, J., Frey, B., 2012. Bacterial, archaeal and fungal succession in the forefield of a receding glacier. Microbial Ecology 63, 552-564. 